\title{
Sensitive high-performance liquid chromatographic fluorescence assay for the quantitation of topotecan (SKF 104864-A) and its lactone ring-opened product (hydroxy acid) in human plasma and urine
}

\author{
W.J. Loos, G. Stoter, J. Verweij, J.H.M. Schellens* \\ Laboratory of Experimental Chemotherapy and Pharmacology, Department of Medical Oncology, Rotterdam Cancer Institutel \\ University Hospital Rotterdam, P.O. Box 5201, 3008 AE Rotterdam, Netherlands
}

Received 1 September 1995; revised 13 November 1995; accepted 20 November 1995

\begin{abstract}
A sensitive reversed-phase high-performance liquid chromatographic fluorescence method is described for the simultaneous determination of topotecan (I) and the hydrolysed lactone ring-opened product hydroxy acid (II) in plasma and for the determination of I in urine. To $250 \mu \mathrm{l}$ of plasma, a 750- $\mu \mathrm{l}$ volume of cold methanol was added to stabilize the $\mathrm{pH}$-dependent conversion of I into II. In plasma, the lower limit of quantitation (LLQ) for both compounds was $0.10 \mathrm{ng} / \mathrm{ml}$. The between-day variation for I at the LLQ was $7.1 \%$ and for II was $5.5 \%$. Prior to injection, urine samples were acidified with orthophosphoric acid and diluted with phosphate-buffered saline (PBS). In urine, the calibration curve for I was linear in the range of 10 to $250 \mathrm{ng} / \mathrm{ml}$ and the LLQ was $10 \mathrm{ng} / \mathrm{ml}$. The assay was developed to enable pharmacological analysis of $\mathrm{I}$, in on-going phase I and II studies, in patients with solid tumors.
\end{abstract}

Keywords: Topotecan

\section{Introduction}

Compound I [ $(S)$-9-dimethylaminomethyl-10-hydroxy-camptothecin, SKF 104864-A] is a semisynthetic water-soluble analogue of camptothecin, presently being evaluated in clinical phase I and II trials. Compound $I$ is an inhibitor of the nuclear enzyme topoisomerase I. It stabilizes the cleavable complex between DNA and topoisomerase I, resulting in single-strand breaks of the DNA and finally in cell death. Antitumor activity has been demonstrated in pre-clinical models and in phase I

\footnotetext{
${ }^{*}$ Corresponding author.
}

and II studies [1-6]. The results of pre-clinical and clinical studies indicate enhanced antineoplastic activity of I when administered daily for prolonged periods of time [2,5-9].

Compound $\mathrm{I}$ is not stable at physiological $\mathrm{pH}$ in an aqueous solution. It is reversibly hydrolysed from the closed-ring lactone (I) to an open-ring form (II) in aqueous solution (Fig. 1). Compound II is not pharmacologically active $[10,11]$.

An HPLC assay for the analysis of I and II in human plasma has previously been developed by Beijnen et al. [11] with a lower limit of quantitation (LLQ), for both compounds, of $1 \mathrm{ng} / \mathrm{ml}$. The present methodology was developed because blank plasma 
<smiles></smiles>

I

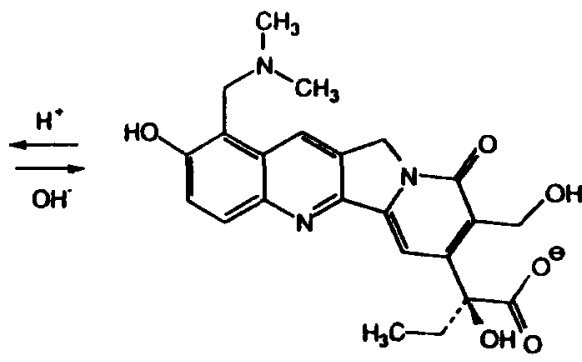

II

Fig. 1. pH-Dependent interconversion of I and II.

samples revealed an interfering peak at almost the same retention time as II. In addition, the plasma concentrations in our clinical study, where $I$ is administered orally for prolonged periods of time, were anticipated to be much lower than the LLQ of the previously developed methodology. Furthermore, an assay for I in urine was developed to determine the magnitude of the renal clearance of $I$ in studies after i.v. administration.

\section{Experimental}

\subsection{Chemicals and reagents}

Compound I was obtained from Smith Kline Beecham Pharmaceuticals (King of Prussia, PA, USA). Methanol (HPLC-grade) was obtained from Rathburn and supplied by Brunschwig (Amsterdam, Netherlands). Triethylamine, potassium dihydrogenphosphate, sodium hydroxide and acetic acid (all analytical grade) were obtained from Baker (Deventer, Netherlands). Orthophosphoric acid (analytical grade) was obtained from Merck (Amsterdam, Netherlands). Phosphate-buffered saline (PBS) was obtained from Oxoid and supplied by Boom (Meppel, Netherlands). PBS consisted of sodium chloride $(8.0 \mathrm{~g} / 1)$, potassium chloride $(0.2 \mathrm{~g} / 1)$, disodium hydrogenphosphate $(1.15 \mathrm{~g} / \mathrm{l})$ and potassium dihydrogenphosphate $(0.2 \mathrm{~g} / \mathrm{l})$ and was supplied in tablet form. One tablet was dissolved in $100 \mathrm{ml}$ of purified water. The water was purified with a MilliQ-UF system (Millipore, Ettenleur, Netherlands).
A stock solution containing $1.0 \mathrm{mg} / \mathrm{ml}$ of I was made by dissolving $50.0 \mathrm{mg}$ of $\mathrm{I}$ in $50.00 \mathrm{ml}$ of purified water. To $5.00 \mathrm{ml}$ of the stock solution in water, $45.00 \mathrm{ml}$ of a $0.10 \%$ acetic acid solution were added. This solution contained $0.10 \mathrm{mg} / \mathrm{ml}$ of $\mathrm{I}$. To another $5.00 \mathrm{ml}$ of the stock solution, $45.00 \mathrm{ml}$ of a $0.10 M$ sodium hydroxide solution were added. This solution contained $0.10 \mathrm{mg} / \mathrm{ml}$ of II.

\subsection{Chromatographic system}

The HPLC system consisted of a constaMetric 4100 pump (Thermo Separations), a Rheodyne 7125 injection port and a fluoriMonitor 4100 fluorescence detector (LDC Analytical). The data were analyzed by the Chrom-Card data analysis system (Fisons). These apparatuses were obtained from Interscience (Breda, Netherlands). The separation was achieved on a Shandon Hypersil BDS $\mathrm{C}_{18}$ column $(100 \mathrm{~mm} \times$ $3 \mathrm{~mm}$ I.D., $3 \mu \mathrm{m}$ particle size), delivered by LC Service (Emmen, Netherlands). A Model $\mathrm{SpH} 99$ column oven, delivered by Spark Holland (Meppel, Netherlands), was set at $35^{\circ} \mathrm{C}$ for the plasma assay and at $60^{\circ} \mathrm{C}$ for the urine assay. The excitation wavelength was set at $381 \mathrm{~nm}$ and the emission wavelength was set at $525 \mathrm{~nm}$.

For the assay in plasma, the mobile phase consisted of $10 \mathrm{~m} M$ potassium dihydrogenphosphate (filtered through a $0.45-\mu \mathrm{m}$ HA Millipore filter, Millipore) containing 25\% methanol and $0.2 \%$ triethylamine. The $\mathrm{pH}$ was adjusted to $\mathrm{pH} 6.0$ by the addition of orthophosphoric acid. The mobile phase 
was degassed using ultrasound and helium. The flow-rate was set at $0.70 \mathrm{ml} / \mathrm{min}$.

For the assay in urine, the mobile phase consisted of $20 \%$ methanol instead of $25 \%$. The flow-rate was set at $1.00 \mathrm{ml} / \mathrm{min}$.

\subsection{Sample preparation and calibration curves in plasma}

Immediately after preparing the standards, $250 \mu \mathrm{l}$ of plasma were added to $750 \mu \mathrm{l}$ of cold methanol of $-20^{\circ} \mathrm{C}$, according to the method of Beijnen et al. [11]. After mixing on a vortex-mixer for $10 \mathrm{~s}$, the samples were centrifuged for $5 \mathrm{~min}$ at $4000 \mathrm{~g}$, at $4^{\circ} \mathrm{C}$, and stored at $-80^{\circ} \mathrm{C}$. Plasma samples from patients were stored, after mixing, at $-80^{\circ} \mathrm{C}$ and centrifuged on the day of analysis. Prior to analysis, $250 \mu \mathrm{l}$ of the supernatant were added to $750 \mu \mathrm{l}$ of PBS and mixed on a vortex-mixer for $10 \mathrm{~s}$. A 200- $\mu \mathrm{l}$ volume was injected into the HPLC.

For the validation of the assay in plasma, a ninepoint calibration curve was processed, in duplicate (Table 1), and analyzed on three occasions. For the determination of the LLQ, six plasma samples from six independent individuals were taken and spiked with $0.10 \mathrm{ng} / \mathrm{ml}$ of both compounds. Also, four pools of quality control (QC) samples were prepared. Plasma pools were spiked with $0.50,2.00,4.00$ and $20.00 \mathrm{ng} / \mathrm{ml}$ of both compounds. The QC sample containing $20.00 \mathrm{ng} / \mathrm{ml}$ was used for subsequent dilutions. On each run, the QC samples were analyzed five times.

The recovery of I and II was determined at concentrations of 2.00 and $4.00 \mathrm{ng} / \mathrm{ml}$ in plasma. The peak heights of five analyzed plasma samples were compared with the peak heights of two spiked concentrations, of 2.00 and $4.00 \mathrm{ng} / \mathrm{ml}$ in PBS.

Calibration curves were made by linear regression analysis of peak heights versus concentration. For the concentration accepted as the LLQ, the percentage deviation (\% DEV) of at least $80 \%$ of the samples assayed should be $\leq 20 \%$. The average within- and between-run precision (\%C.V.) for each concentration, excluding the LLQ, should be $\leq 15 \%$ and should be $\leq 20 \%$ for the LLQ. The average accuracy $(\%)$ for each concentration, including the LLQ, should be within 85-115\%.

\subsection{Urine sample preparation and calibration curve}

In urine, the total concentration of I was measured after conversion of II into I. To $250 \mu \mathrm{l}$ of urine, 250 $\mu 1$ of a 100 -fold dilution of pure orthophosphoric acid were added. After mixing on a vortex-mixer for $10 \mathrm{~s}$, the mixture was incubated for at least $10 \mathrm{~min}$ at room temperature. Prior to injection, $50 \mu \mathrm{l}$ of this mixture were added to $950 \mu \mathrm{l}$ of PBS and mixed on a vortex-mixer for 10 s. A $20-\mu$ l volume was injected into the HPLC.

For the validation of the assay in urine, a sevenpoint calibration curve was prepared (Table 2). The calibration curves were made in duplicate and analyzed on three occasions. For the determination of the LLQ, ten urine samples from ten independent individuals were taken and spiked with $10 \mathrm{ng} / \mathrm{ml}$ of I. Pools of QC samples were spiked with 25,100 , 200 and $1000 \mathrm{ng} / \mathrm{ml}$ of I. The QC sample of 1000 $\mathrm{ng} / \mathrm{ml}$ was used for all subsequent dilutions. In each run, the QC samples were processed five times.

The recovery of I was determined at concen-

Table 1

Preparation of the calibration curves in plasma

\begin{tabular}{llllllllll}
\hline & \multicolumn{1}{l}{ Final concentration of I and II $(\mathrm{ng} / \mathrm{ml})$} \\
\cline { 2 - 10 } & 5.00 & 3.00 & 2.00 & 1.00 & 0.50 & 0.30 & 0.20 & 0.15 & 0.10 \\
\hline Plasma added $(\mu \mathrm{l})$ & 500 & 700 & 800 & 1800 & 500 & 700 & 800 & 850 & 900 \\
$10.0 \mathrm{ng} / \mathrm{ml}$ I and II added $(\mu \mathrm{l})$ & 500 & 300 & 200 & 200 & & & & \\
$1.00 \mathrm{ng} / \mathrm{ml}$ I and II added $(\mu \mathrm{l})$ & & & & & 500 & 300 & 200 & 150 & 100 \\
\hline
\end{tabular}

Solutions containing $0.10 \mathrm{mg} / \mathrm{ml}$ of I and $0.10 \mathrm{mg} / \mathrm{ml}$ of II were separately diluted 100 -fold with PBS and again 10-fold with plasma. A-200 $\mu \mathrm{l}$ volume of both solutions was added to $1600 \mu \mathrm{l}$ of plasma. This solution contained $10.0 \mathrm{ng} / \mathrm{ml}$ of I and II. 
Table 2

Preparation of the calibration curve in urine

\begin{tabular}{|c|c|c|c|c|c|c|c|}
\hline & \multicolumn{7}{|c|}{ Final concentration of $\mathrm{I}(\mathrm{ng} / \mathrm{ml})$} \\
\hline & 250 & 200 & 150 & 100 & 50 & 25 & 10 \\
\hline Urine added $(\mu 1)$ & 750 & 800 & 850 & 900 & 500 & 500 & 900 \\
\hline $1000 \mathrm{ng} / \mathrm{ml}$ of $\mathrm{I}$ added $(\mu \mathrm{l})$ & 250 & 200 & 150 & 100 & & & \\
\hline $100 \mathrm{ng} / \mathrm{ml}$ of $\mathrm{I}$ added $(\mu \mathrm{l})$ & & & & & 500 & & 100 \\
\hline $50 \mathrm{ng} / \mathrm{ml}$ of $\mathrm{I}$ & & & & & & 500 & \\
\hline
\end{tabular}

A solution containing $0.10 \mathrm{mg} / \mathrm{ml}$ of $\mathrm{I}$ was diluted 100 -fold in urine. This results in a $1000 \mathrm{ng} / \mathrm{ml}$ solution of $\mathrm{I}$.

trations of 100 and $200 \mathrm{ng} / \mathrm{ml}$ in urine. The procedure is the same as the procedure described for plasma.

Calibration curves were constructed by linear regression analysis of peak heights versus concentration. The same acceptance criteria were applied as those described for plasma samples.

\subsection{Stability of I and II in plasma and urine}

The stability of I and II was tested in plasma extracts and in urine at different temperatures.

In plasma, the stability of both compounds was tested by incubating plasma with extracts containing either I alone or II alone, for $24 \mathrm{~h}$ at room temperature $\left(22^{\circ} \mathrm{C}\right), 4^{\circ} \mathrm{C}$ and at $-20^{\circ} \mathrm{C}$. The stability at $-80^{\circ} \mathrm{C}$, the storage temperature for patients' samples, was tested with methanolic plasma mixtures containing both compounds.

In urine, the stability of I was tested by incubation of urine with $\mathrm{I}$ for $24 \mathrm{~h}$ at $4^{\circ} \mathrm{C}, 22^{\circ} \mathrm{C}$ and at $37^{\circ} \mathrm{C}$ and also in urine that was diluted one-fold with orthophosphoric acid $(1: 100, \mathrm{v} / \mathrm{v})$, at $22^{\circ} \mathrm{C}$. Also, the stability of $\mathrm{I}$ in urine, at $-80^{\circ} \mathrm{C}$, was tested.

\subsection{Human experiments}

In an oral phase I study, the starting dose was 0.15 $\mathrm{mg} / \mathrm{m}^{2}$. On days 1 and 8 , blood samples were collected for up to $12 \mathrm{~h}$. One of the first patients was treated with a dose of $0.4 \mathrm{mg}$. Immediately after sampling, the blood was centrifuged for $5 \mathrm{~min}$ at $3500 \mathrm{~g}$ and the plasma was treated as outlined.

In another study, where I is administered intravenously at a low daily dose of $0.5 \mathrm{mg} / \mathrm{m}^{2}$, urine samples were collected also.

\section{Results}

\subsection{Assay in plasma}

The calibration curves of I and II in plasma were linear in the range of 0.10 to $5.00 \mathrm{ng} / \mathrm{ml}$, with correlation coefficients of at least 0.9986 . The retention time of II is $2.5 \mathrm{~min}$ and that of $I$ is $6.5 \mathrm{~min}$ (Fig. 2). No significant interfering peaks were found in six independent blank plasma samples. The LLQ for both compounds in plasma was $0.10 \mathrm{ng} / \mathrm{ml}$. The mean recovery of I in plasma was $99.3 \%$ and of II was $100.6 \%$. The within-run precision of the LLQ samples of I was $4.4 \%$ and of II was $9.7 \%$. The accuracies were $93.2 \%$ and $106.6 \%$, respectively. The between-run precision of the LLQ was calculated using the lowest concentration of the individual calibration curves used for the validation of the assay. The between-run precisions were 7.1 and $5.5 \%$, respectively. The average values for the accuracy, within-run precision and the between-run precision of the QC samples are given in Table 3.

\subsection{Assay in urine}

The calibration curves of $I$ in urine were linear in the range of 10 to $250 \mathrm{ng} / \mathrm{ml}$ with correlation coefficients of at least 0.9984 . Also for the assay in urine no significant interfering peaks for I were found. The LLQ was established at $10 \mathrm{ng} / \mathrm{ml}$ (concentrations in the clinical studies were not expected to be lower than $10 \mathrm{ng} / \mathrm{ml}$ ). The mean recovery of $I$ in urine was $101.9 \%$. The within-run precision of the LLQ samples was $7.2 \%$, the between-run precision was $5.4 \%$ and the accuracy of the LLQ was $97.6 \%$. The average values of the accuracy, the within-run precision and the between- 

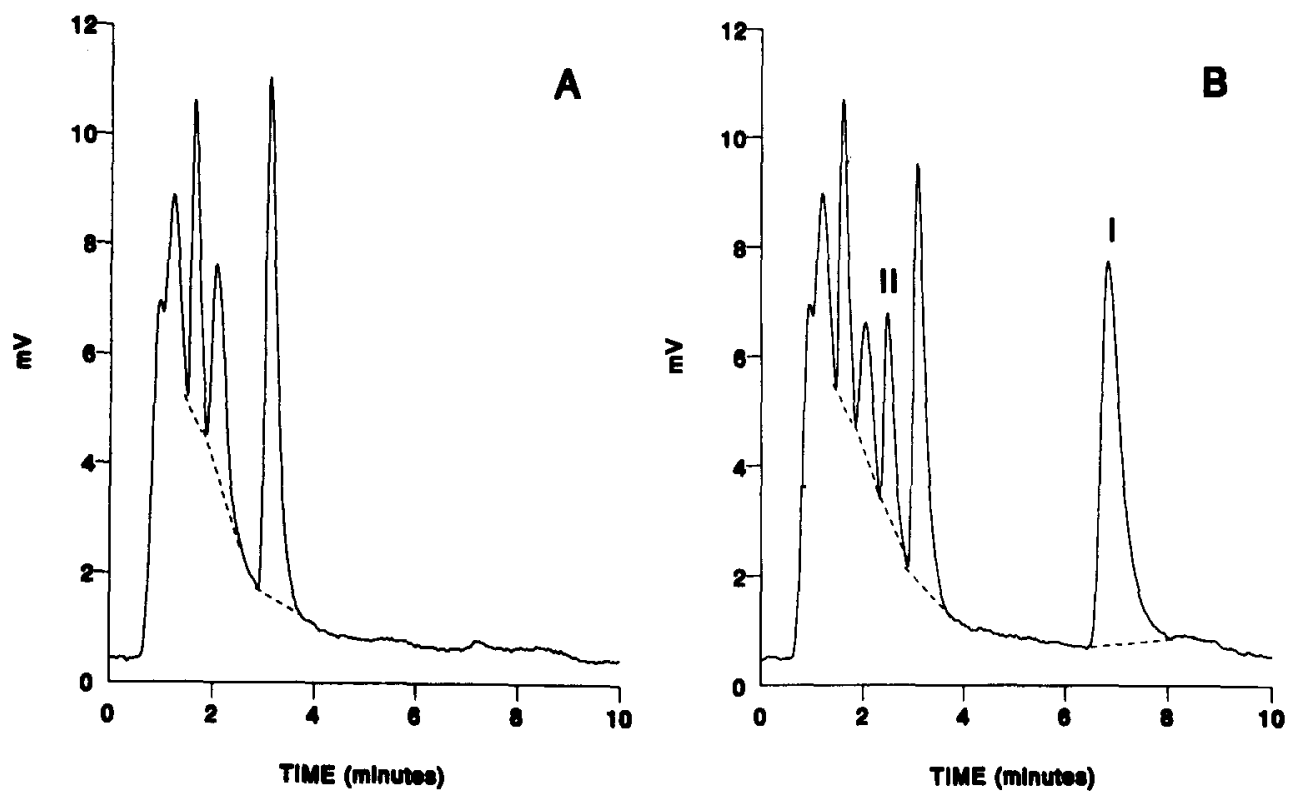

Fig. 2. Chromatograms of a blank blood sample (A) and of a blood sample containing $0.78 \mathrm{ng} / \mathrm{ml}$ of I and $0.24 \mathrm{ng} / \mathrm{ml}$ of Il (B).

run precision of the QC samples are given in Table 4.

\subsection{Stability of I and II in plasma and of I in urine}

The reversible hydrolysis of I in plasma extracts is dependent on the temperature. Compounds I and II were found to be unstable at $4^{\circ} \mathrm{C}$ and at $22^{\circ} \mathrm{C}$. There was no hydrolysis at $-20^{\circ} \mathrm{C}$ (Fig. 3). Compounds I and II were stable in methanolic plasma mixtures for at least 4 months at $-80^{\circ} \mathrm{C}$.

The stability of $\mathrm{I}$ in urine was also dependent on the temperature. At $37^{\circ} \mathrm{C}$, I was found to be unstable, at $22^{\circ} \mathrm{C}$ it was moderately stable and at $4^{\circ} \mathrm{C}$, I was stable for $24 \mathrm{~h}$. Compound I was stable at $22^{\circ} \mathrm{C}$ after dilution with orthophosphoric acid (Fig. 4). At $-80^{\circ} \mathrm{C}$, I was stable for more than 3 months.

\subsection{Human experiment}

The plasma concentration-time curves of I and II from the patient treated with $0.4 \mathrm{mg}$ of I are given in Fig. 5.

The concentration of $I$ in the urine samples of

Table 3

The average accuracy, within-run precision and between-run precision of I and II in the QC samples in plasma

\begin{tabular}{|c|c|c|c|c|c|c|}
\hline \multirow{3}{*}{$\begin{array}{l}\text { QC sample } \\
(\mathrm{ng} / \mathrm{ml})\end{array}$} & \multicolumn{2}{|c|}{ Average accuracy (\%) } & \multicolumn{4}{|c|}{ Precision (\%) } \\
\hline & \multirow[t]{2}{*}{ I } & \multirow[t]{2}{*}{ II } & \multicolumn{2}{|c|}{ Within-run (mean) } & \multicolumn{2}{|c|}{ Between-run } \\
\hline & & & I & II & I & II \\
\hline 0.50 & 102.7 & 101.3 & 2.8 & 1.5 & 6.9 & 6.3 \\
\hline 2.00 & 108.4 & 106.5 & 3.8 & 1.3 & 8.6 & 5.2 \\
\hline 4.00 & 102.8 & 102.6 & 3.1 & 1.0 & 5.0 & 5.5 \\
\hline 20.00 & 103.3 & 102.3 & 3.9 & 3.7 & 3.0 & 3.5 \\
\hline
\end{tabular}


Table 4

The average accuracy, within-run precision and between-run precision of $I$ in the $Q C$ samples in urine

\begin{tabular}{llll}
\hline $\begin{array}{l}\text { QC sample } \\
(\mathrm{ng} / \mathrm{ml})\end{array}$ & Average accuracy $(\%)$ & Precision $(\%)$ & \\
\cline { 3 - 4 } & & Within-run (mean) & Between-run \\
\hline 25 & 99.7 & 4.4 & 3.3 \\
100 & 97.5 & 4.1 & 0.6 \\
200 & 97.8 & 5.3 & 1.8 \\
1000 & 98.9 & 3.2 & 2.0 \\
\hline
\end{tabular}

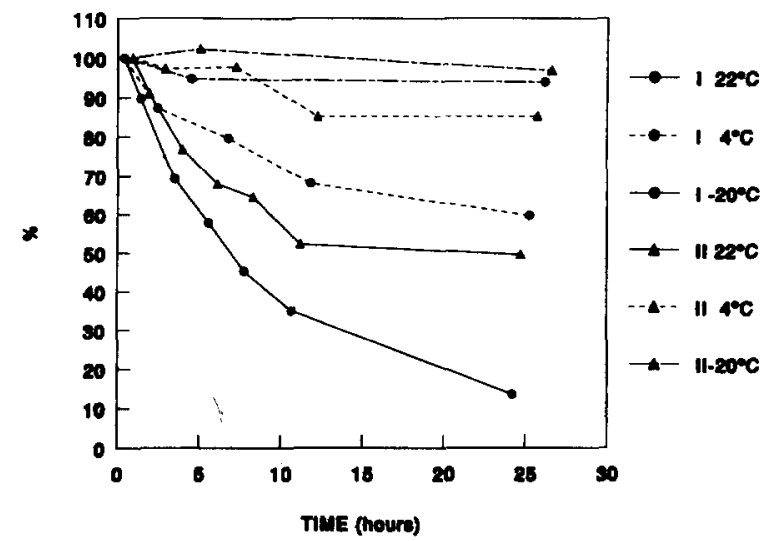

Fig. 3. Stability of I and II in plasma extracts, at different temperatures for $24 \mathrm{~h}$.

patients who were treated using the intravenous protocol were all $>10 \mathrm{ng} / \mathrm{ml}$ (data not shown).

\section{Discussion}

The described methodology for the assay in plasma with an LLQ of $0.10 \mathrm{ng} / \mathrm{ml}$ for I and II is

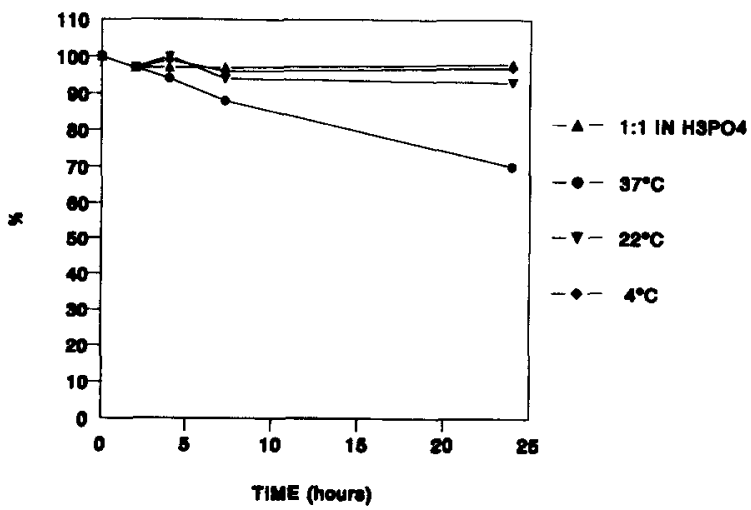

Fig. 4. Stability of $I$ in urine at different temperatures and when diluted one-fold with orthophosphoric acid. appropriate for the measurement of plasma samples in ongoing clinical studies, where low daily doses are administered. For the assay in urine, the LLQ of $10 \mathrm{ng} / \mathrm{ml}$ was also satisfactory. Both compounds were unstable in plasma extracts at $4^{\circ} \mathrm{C}$ and at $22^{\circ} \mathrm{C}$. In urine, I was found to be unstable at $37^{\circ} \mathrm{C}$ and moderately stable at $22^{\circ} \mathrm{C}$. Methanolic plasma mixtures and urine stored at $-80^{\circ} \mathrm{C}$ were found to be stable for at least 4 and 3 months, respectively.

In urine, only I was measured after acidification, to ensure total conversion of II into I.

\section{Conclusion}

A sensitive, selective, accurate and reproducible isocratic reversed-phase HPLC method has been developed for the simultaneous analyses of I and II in plasma and for the analysis of I in urine. Plasma sample pretreatment was carried out immediately after sample collection by deproteinizing the sample with cold methanol, as previously described [11]. Prior to injection, the sample was diluted with PBS. The urine samples were analyzed after acidification

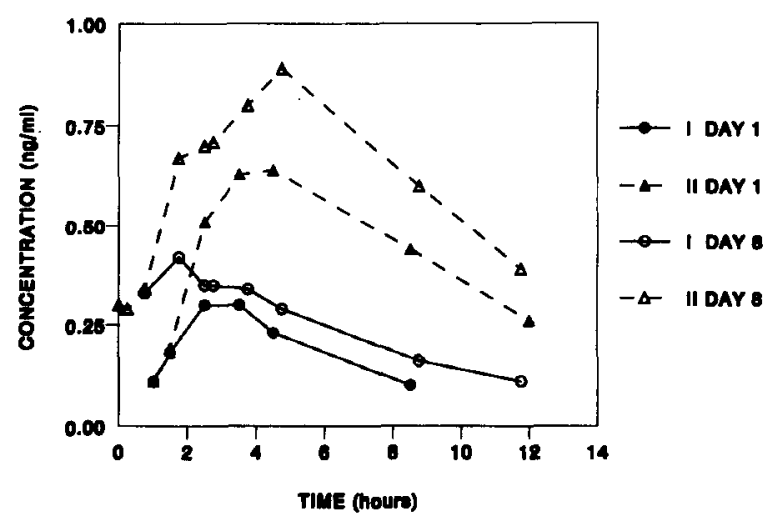

Fig. 5. Plasma concentration-time curve of I and II after oral administration of $0.4 \mathrm{mg}$ on days 1 and 8 . 
with orthophosphoric acid and dilution with PBS. The methodology described for the measurement of plasma concentrations of both compounds and of urine concentrations of I can be used to determine the pharmacokinetics in clinical studies when $I$ is administered at low doses.

\section{References}

[1] R.K. Johnson, F.L. McCabe, G. Gallagher, J. Wood, J. Galef and R.P. Herzberg, Ann. Oncol., 3 (Suppl. 1) (1992) 85.

[2] E.K. Rowinsky, L.B. Grochow, C.B. Hendricks, D.S. Ettinger, A.A. Forastiere, L.A. Hurowithz, W.P. McGuire, S.E. Sartorius, B.G. Lubejko, S.H. Kaufman and R.C. Donehower, J. Clin. Oncol., 10 (1992) 647.

[3] J.G. Wall, H. Burris, D. Von Hoff, G. Rodriguez, R. KneuperHall, D. Shaffer, T. O'Rourke, T. Brown, G. Weiss, G. Clark, S. McVea, J. Brown, R.K. Johnson, C. Friedman, B. Smith, W.S. Mann and J. Kuhn, Anti Cancer Drugs, 3 (1992) 337.
[4] S.M. Blaney, F.M. Balis, D.E. Cole, C. Craig, J.M. Reid, M.M. Ames, M. Krailo, G. Reaman, D. Hammond and DG. Poplack, Cancer Res., 53 (1993) 1032.

[5] H. Hochster, J. Speyer, R. Oratz, M. Meyers, J. Werns, A. Chachoua, B. Raphael, J. Sorich, B. Taubes, L. Liebes, D. Fry and R. Blum, J. Clin. Oncol., 12 (1991) 553

[6] J.H.M. Schellens, L.C. Pronk and J. Verweij, Drugs, in press (1996).

[7] B.C. Giovanella, J.S. Stehlin, M.E. Wall, M.C. Wani, A.W. Nicholas, L.F. Liu, R. Silber and M. Potmesil, Science, 246 (1989) 1046.

[8] H.A. Burris, A.R. Hanauske, R.K. Johnson, M.H. Marshall, J.G. Kuhn, S.G. Hilsenbeck and D.D. Von Hoff, J. Natl. Cancer Inst., 84 (1992) 1816.

[9] P.J. Houghton, P.J. Cheshire, L. Myers and J.A. Houghton, Cancer Chemother. Pharmacol., 31 (1992) 229.

[10] J. Verweij, B. Lund, J.H. Beijnen, A.S.Th. Planting, M. Boer-Dennert, de, I. Koier, H. Rosing and H. Hansen, Ann. Oncol., 4 (1993) 673.

[11] J.H. Beijnen, B.R. Smith, W.J. Keijer, R. van Gijn, W.W. Ten Bokkel-Huinink, L.Th. Vlasveld, S. Rodenhuis and W.J.M. Underberg, J. Pharm. Biomed. Anal., 8 (1990) 789. 